\title{
Multiple drug resistance in bacterial isolates from liquid wastes generated in central hospitals of Nepal
}

\section{Sharma DR ${ }^{1}$, Pradhan B ${ }^{2}$, Mishra SK ${ }^{3}$}

${ }^{1}$ Lecturer, Department of Public Health, Yeti Health Science Academy, Kathmandu, Nepal, ${ }^{2}$ Associate Professor, Department of Community Medicine and Family Health, Institute of Medicine, Kathmandu Nepal, ${ }^{3}$ Assistant Professor, Department of Clinical Biochemistry, Kantipur Dental College, Kathmandu, Nepal.

\begin{abstract}
Background: Healthcare liquid wastes are the reservoirs of harmful infectious agents such as the pathogens and multiple drug resistant microorganisms. Potential infectious risks include the spread of infectious diseases and microbial resistance from health-care establishments into the environment and thereby posing risks of getting infections and antibiotic resistance in the communities.

Objectives: The objectives of this study were to assess the bacterial load of healthcare liquid waste generated in central hospitals and to explore the antimicrobial resistance pattern of these bacterial isolates.

Materials and methods: A descriptive study was carried out in 10 conveniently selected central hospitals of Nepal during the period of May to December 2008. Effluent specimens from each hospital were subjected to total viable count studies by spread plate method in nutrient agar plate and incubated for 24 hours at $37^{\circ} \mathrm{C}$ using standard laboratory protocol. Similarly, all the specimens were cultured in Mac Conkey Agar media supplemented with $30 \mu \mathrm{g} / \mathrm{ml}$ of Chloramphenicol and $20 \mu \mathrm{g} / \mathrm{ml}$ of Gentamycin for the enumeration of multiple drug resistant (MDR) bacteria, which were further subjected to in-vitro antibiotic susceptibility test by modified Kirby Bauer disc diffusion technique for resistance patterns.

Results: Total viable counts of hospital effluents significantly exceeded the standard heterotrophic plate count $(\mathrm{p}=0.000)$. Similarly, the numbers of multiple drug resistant bacteria were alarmingly high in three (more than $30 \%$ in 2 and $50 \%$ in 1) hospitals of this study. Drug resistant hospital effluent isolates showed simultaneous resistance for most of the antibiotics including Penicillin, Cephalosporin, Cotrimoxazole, Gentamycin and Quinolones.

Conclusion: Healthcare liquid wastes were laden with MDR bacteria and seemed to pose a huge public health threat in the transfer of such resistance to the bacterial pathogens causing community acquired infections, thereby limiting our antibiotic pool.
\end{abstract}

Key words: Healthcare liquid waste management, viable count, multiple drug resistance, hospitals, Nepal

$\mathrm{T}$ he sources of liquid waste in the hospital include outdoor and indoor departments, operation theatres, laboratories (microbiology, biochemistry, histopathology, blood bank, etc.), radiology and others. The major concern is the disposal of infectious wastes such as cultures and stocks of infectious agents, wastes from infected patients, wastes contaminated with blood and its derivatives, discarded diagnostic samples, infected animals from laboratories, and contaminated materials (swabs, bandages) and equipment (disposable medical devices etc. $)^{1}$.

The basic principle of underlying wastewater management is the strict limit on the discharge of hazardous liquids into sewers without prior treatment ${ }^{2}$ so that living pathogenic organisms are not introduced into the environment. However, in Nepal, only the towns in Kathmandu Valley have a sewerage network system and the sewerage facility is provided to $15 \%$ of the houses only ${ }^{3}$. Furthermore, four out of five municipal wastewater treatment plants are non functional. Since all the hospitals in different locations are not covered by the sewerage networks, majority of the healthcare institutions have been discharging their effluents onto surface water (rivers). Therefore, even if the hospitals are discharging their healthcare liquid waste into sewerage system, it is mixed with the sewage and gets in surface water without proper treatment. If the hospital effluents are not treated, concentrated forms of

Correspondence

Dhundi Raj Sharma

Lecturer, Department of Public Health

Yeti Health Science Academy, Kathmandu, Nepal

E-mail: dsharmadr@hotmail.com 
infectious agents and antibiotic resistant microbes are shed into communities resulting in water borne diseases such as cholera, typhoid fever, dysentery and gastroenteritis.

Antibiotics, disinfectants and bacteria resistant to them have been detected in the environmental compartments such as waste water, surface water, ground water, sediments and soils ${ }^{4}$. Studies have discovered trace level concentrations of antibiotics in waste water treatment plant effluents and surface waters ${ }^{5}$. Longterm exposure of microorganisms to low concentrations of antibiotics in wastewater and surface water has the potential for the development of antibiotic resistance in these organisms ${ }^{6}$.

The concerns about antimicrobial resistance are increasing. In a report by the United Kingdom House of Lords, it is stated that the resistance to antibiotics and other anti-infective agents constitutes a major threat to public health and ought to be recognized as such more widely than it is at present ${ }^{7}$. Input of resistant bacteria as well as of antibiotics can disturb the established wellbalanced and important interdependencies ${ }^{8}$. The input of resistant bacteria into the environment seems to be an important source of resistance in the environment. Therefore, the development of antibiotic resistance in bacteria and their dissemination in the environment is of serious public health concern because an individual patient can develop an antibiotic resistant infection by contacting a resistant organism and spread in the communities.

Hospitals and public health care units must safeguard the health of the community. However, the waste produced by the health care centres if disposed of improperly, can pose an even greater threat than the original diseases themselves due to the presence of concentrated forms of numerous risks including pathogenic and antibiotic resistant microorganisms. In Nepal, where several thousand die due to infectious diseases and several more losing quality of lives, untreated hospital liquid waste discharge into surface water directly or indirectly must have been adding more problems. It is our common observation that majority of the healthcare facilities do not practice safe healthcare liquid waste treatment and disposal. In such scenario, this study was carried out to explore the multiple drug resistance of bacterial isolates in healthcare liquid waste generated from Kathmandu based central hospitals of Nepal.

\section{Materials and methods}

It was a cross sectional study conducted in Kathmandu based central hospitals during the period of May to December 2008. Primary data were collected by microbiology laboratory works, for which, $150 \mathrm{ml}$ of triplicate hospital effluent water specimens from each of ten hospitals were collected from the outermost chambers before discharging into the sewerage system by following standard procedures of microbiology laboratory. Each specimen was brought to the laboratory within an hour of collection and cultured for total viable counts in Nutrient Agar medium by spread plate method.

Similarly, all specimens were cultured in Mac Conkey Agar media supplemented with $30 \mu \mathrm{g} / \mathrm{ml}$ of Chloramphenicol and $20 \mu \mathrm{g} / \mathrm{ml}$ of Gentamycin by spread plate method for the enumeration of multiple drug resistant (MDR) bacteria. These bacterial isolates were identified as Escherichia, Citrobacter, Enterobacter, Klebsiella, Pseudomonas, Acinetobacter, Proteus and Enterococcus species based on morphological characteristics, gram's staining and biochemical tests and tested for antibiotic sensitivity assays by Kirby Bauer disc diffusion technique for a group of antibiotics. All the media and antibiotic discs were obtained from Hi-Media.

One sample $t$ test and $t$ test for independent means were performed to compare the means of total viable counts of hospital effluents with standard heterotrophic plate count.

\section{Results}

The mean of total viable bacterial counts ranged from $12.3 \times 10^{6} \mathrm{cfu} / \mathrm{ml}$ in hospital $\mathrm{H} 2$ to $56.0 \times 10^{6} \mathrm{cfu} / \mathrm{ml}$ in hospital H5. Similarly, the Multiple Drug Resistant bacteria ranged from $1.67 \%$ in $\mathrm{H} 5$ to over $50.00 \%$ in H4. Hospitals $\mathrm{H} 3, \mathrm{H} 4$ and $\mathrm{H} 8$ showed very high percentages of 33.45, 50.37 and 42.81 MDR bacteria respectively (Table 1).

Commonly used antibiotics from common groups viz. Penicillin, Cephalosporins, Quinolones, Aminoglycosides, Chloramphenicol, Cotrimoxazole and Nitrofurantoin were tested for the resistance patterns of MDR bacteria isolated from the hospital effluents. These MDR bacteria were resistant to the groups of Penicillins, Cephalosporins, Quinolones, Aminoglycosides and other antibiotic assayed in this study except for Amikacin and Nitrofurantoin, where all the isolates from $\mathrm{H} 1$ to $\mathrm{H} 10$ were sensitive to the former and partially resistant to the latter antibiotic (Table 2). The designation 'partially resistant' was given to those hospitals where some organisms were sensitive and the others were resistant to Nitrofurantoin. 
Table 1: Total number and percentage distribution of MDR bacteria in hospital effluent

\begin{tabular}{|c|c|c|c|}
\hline $\begin{array}{c}\text { Hospital effluent } \\
\text { code (Bed No.) }\end{array}$ & $\begin{array}{c}\text { Mean of total viable bacterial } \\
\text { count } \pm \text { standard deviation } \\
\left(\mathbf{x} \mathbf{1 0}^{\mathbf{6}} \mathbf{c f u} / \mathbf{m l} \text { ) bacterial }\right.\end{array}$ & $\begin{array}{c}\text { Mean of MDR bacterial } \\
\text { count } \pm \text { standard deviation } \\
\mathbf{( x ~ 1 0 5} \mathbf{c f u} / \mathbf{m l})\end{array}$ & $\begin{array}{c}\text { Percentage } \\
\text { MDR }\end{array}$ \\
\hline H1 (50) & $34.0 \pm 17.0$ & $7.0 \pm 2.0$ & 2.05 \\
\hline H2 (458) & $12.3 \pm 8.0$ & $7.0 \pm 3.0$ & 5.70 \\
\hline H3 (279*) & $29.0 \pm 18.0$ & $97.0 \pm 21.0$ & 33.45 \\
\hline H4 (454*) & $40.7 \pm 11.0$ & $205.0 \pm 57.0$ & 50.37 \\
\hline H5 (100) & $56.0 \pm 17.0$ & $9.3 \pm 6.0$ & 1.67 \\
\hline H6 (401) & $51.0 \pm 7.0$ & $87.0 \pm 30.0$ & 1.70 \\
\hline H7 (200) & $44.7 \pm 13.0$ & $13.0 \pm 8.0$ & 2.91 \\
\hline H8 (700**) & $32.7 \pm 14.0$ & $140.0 \pm 61.0$ & 42.81 \\
\hline H9 $(50)$ & $15.3 \pm 12.0$ & $6.0 \pm 3.0$ & 3.92 \\
\hline H10 $(700)$ & $48.0 \pm 12.0$ & $12.0 \pm 4.0$ & 2.50 \\
\hline
\end{tabular}

* Hospitals having treatment plants ** Hospital having central collection of all waste water

Table 2: Resistance patterns of MDR bacteria isolated from hospital effluents

\begin{tabular}{|l|l|c|c|c|c|c|c|c|c|c|c|}
\hline Antibiotic group & Antibiotics/ concentration* & H1 & H2 & H3 & H4 & H5 & H6 & H7 & H8 & H9 & H10 \\
\hline Penicillins & Ampicillin (10) & R & R & R & R & R & R & R & R & R & R \\
\hline & $\begin{array}{l}\text { Piperacillin (100)+ } \\
\text { tazobactam(10) }\end{array}$ & $\mathrm{R}$ & $\mathrm{R}$ & $\mathrm{R}$ & $\mathrm{R}$ & $\mathrm{R}$ & $\mathrm{R}$ & $\mathrm{R}$ & $\mathrm{R}$ & $\mathrm{R}$ & $\mathrm{R}$ \\
\hline Cephalospirins & Cephalexin (30) & $\mathrm{R}$ & $\mathrm{R}$ & $\mathrm{R}$ & $\mathrm{R}$ & $\mathrm{R}$ & $\mathrm{R}$ & $\mathrm{R}$ & $\mathrm{R}$ & $\mathrm{R}$ & $\mathrm{R}$ \\
\hline & Ceftazidime (30) & $\mathrm{R}$ & $\mathrm{R}$ & $\mathrm{R}$ & $\mathrm{R}$ & $\mathrm{R}$ & $\mathrm{R}$ & $\mathrm{R}$ & $\mathrm{R}$ & $\mathrm{R}$ & $\mathrm{R}$ \\
\hline & Cefotaxime (30) & $\mathrm{R}$ & $\mathrm{R}$ & $\mathrm{R}$ & $\mathrm{R}$ & $\mathrm{R}$ & $\mathrm{R}$ & $\mathrm{R}$ & $\mathrm{R}$ & $\mathrm{R}$ & $\mathrm{R}$ \\
\hline Quinolones & Ciprofloxacin (5) & $\mathrm{R}$ & $\mathrm{R}$ & $\mathrm{R}$ & $\mathrm{R}$ & $\mathrm{R}$ & $\mathrm{R}$ & $\mathrm{R}$ & $\mathrm{R}$ & $\mathrm{R}$ & $\mathrm{R}$ \\
\hline Aminoglycosides & Amikacin (30) & $\mathrm{S}$ & $\mathrm{S}$ & $\mathrm{S}$ & $\mathrm{S}$ & $\mathrm{S}$ & $\mathrm{S}$ & $\mathrm{S}$ & $\mathrm{S}$ & $\mathrm{S}$ & $\mathrm{S}$ \\
\hline & Gentamycin (10) & $\mathrm{R}$ & $\mathrm{R}$ & $\mathrm{R}$ & $\mathrm{R}$ & $\mathrm{R}$ & $\mathrm{R}$ & $\mathrm{R}$ & $\mathrm{R}$ & $\mathrm{R}$ & $\mathrm{R}$ \\
\hline Others & Nitrofurantoin (300) & $\mathrm{PR}$ & $\mathrm{PR}$ & $\mathrm{PR}$ & $\mathrm{PR}$ & $\mathrm{PR}$ & $\mathrm{PR}$ & $\mathrm{PR}$ & $\mathrm{PR}$ & $\mathrm{PR}$ & $\mathrm{PR}$ \\
\hline & Cotrimoxazole (23.75+1.25) & $\mathrm{R}$ & $\mathrm{R}$ & $\mathrm{R}$ & $\mathrm{R}$ & $\mathrm{R}$ & $\mathrm{R}$ & $\mathrm{R}$ & $\mathrm{R}$ & $\mathrm{R}$ & $\mathrm{R}$ \\
\hline & Chloramphenicol (30) & $\mathrm{R}$ & $\mathrm{R}$ & $\mathrm{R}$ & $\mathrm{R}$ & $\mathrm{R}$ & $\mathrm{R}$ & $\mathrm{R}$ & $\mathrm{R}$ & $\mathrm{R}$ & $\mathrm{R}$ \\
\hline
\end{tabular}

*Drug concentration in $\mu \mathrm{g} /$ disc mentioned in parentheses; $\mathrm{R}=$ Resistant; $\mathrm{PR}=$ Partially Resistant; $\mathrm{S}=\mathrm{Sensitive}$

\section{Discussion}

The total viable counts in hospitals with and without treatment plants were not found to be significantly different $(p=0.232)$ while compared by $t$ test for independent means. This means that the treatment plants were non-functional. All the total counts enumerated in hospital effluent specimens heavily exceeded the standard heterotrophic plate count of $104 \mathrm{cfu} / \mathrm{ml}(\mathrm{p}=0.000)$, as shown by one sample $\mathrm{t}$ test. These findings suggest that the hospital waste water has been discharged without treatment. This implies that the pathogenic organisms might also have been present in such hospital waste water and public health is at stake unless these are not treated either in the hospital or waste water treatment plants of the sewerage system.

Hospital H1 with bed capacity only 50 had total count of $34.0 \pm 17.0 \times 106 \mathrm{cfu} / \mathrm{ml}$ whereas hospital H2 with bed capacity 458 had total count of $12.3 \pm 8.0$ X 106 $\mathrm{cfu} / \mathrm{ml}$. This means that hospital bed capacity does not necessarily influence the total viable count of bacteria. Hospitals H3, H4 and H8 showed very high percentages of 33.45, 50.37 and 42.81 MDR bacteria, two of which had treatment plants and the other had central collection of all waste generated in the hospital. The highest percentage (more than $50.0 \%$ ) of multiple drug resistant bacteria was found to be even greater than that of a similar study carried out in India ${ }^{9}$ where it was only $40.0 \%$. Such bigger MDR percentages could be attributed to the nonfunctioning operating status of the treatment plants in addition to excessive use of antimicrobials to treat higher number of patients in these hospitals resulting in increased selective pressure for the bacteria. This is further supported by the fact of the significantly higher numbers of MDR bacteria in the 
hospitals with treatment plants than those of not having such plants $(\mathrm{p}=0.01)$. The possible explanation for this difference is that bacteria are not killed; get enough time to mix, proliferate and drug resistant plasmids from MDR bacteria get transferred to otherwise sensitive bacterial population inside the non-functioning plant. Therefore, having non-functional treatment plant seems even more dangerous than the others in disseminating MDR bacteria apart from the possible presence of pathogens. This finding should mean that if treatment plants are functional, all pathogenic and MDR bacteria are killed and the safe waste water is disposed.

One study carried out in Bangladesh in 2007 found out that the resistance development was directly related to the use of antibiotics ${ }^{10}$. The results further suggested that the multi-drug resistant bacteria \& plasmid containing multi drug resistant genes present in the hospital waste might act as a possible source of transfer of these highly resistant genes to the bacterial population. The bacterial strains susceptible to Gentamycin and Chloramphenicol but resistant to other antibiotics must not have been grown. The number of MDR bacteria was still alarmingly high for the effluent samples from hospitals. More distressing was the pattern of MDR. Simultaneous resistance for most of the antibiotics including penicillin, Cephalosporin, Cotrimoxazole, Gentamycin and Quinolones formed the MDR pattern. This pattern of antimicrobial resistance in bacteria is highly consistent with the results of the study carried out in India ${ }^{9}$. The pattern was almost the same for the various genera grown from the effluent samples. The MDR pattern seen in the bacterial isolates from hospital effluent samples included many of the antibiotics being currently used in the treatment of infectious diseases.

In a study carried out in Madrid, Spain, the spread of $E$ coli strains with high level of Cefotaxime and Ceftazidime resistance between community, long term care facilities and hospital institutions showed that epidemic or occasional isolates of Ceftazidime and Cefotaxime resistant $E$ coli can spread between distinct health facilities including hospital, community health centres and long term care centres ${ }^{11}$. Such broad disseminations of high level of Ceftazidime and Cefotaxime resistant $E$ coli raise the important clinical and epidemiological concerns. Similarly another study conducted in California showed that a single clone of community associated methicillin resistant $S$ aureus (MRSA) accounted for the majority of infections, which was originated in the community and not related to MRSA strains of healthcare settings ${ }^{12}$. These studies suggest that resistance is transferable amongst bacteria.
Therefore, the worst fear is the transfer of such resistance to bacterial pathogens causing infections and their spread in the communities. In that case most of the currently available antimicrobials will not work against the disease agents. The origin of such MDR bacterial strains appears to be the hospital environment and the selective pressure responsible for expanding such bacterial populations in hospitals must have been through the use of drugs in humans and not from their use in the veterinary and agriculture field as pointed out by Walton ${ }^{13}$. It is theoretically possible that resistance is spread and all bacterial populations could be dominated by MDR bacteria in the future and we shall have to see the patients dying from simple infections due to unavailability of antimicrobials working against them. The possible solution to the problem of MDR bacteria in healthcare liquid waste is to kill the same through the establishment of waste water treatment plant and monitoring their functional status regularly so that the microbes are killed and could not be disseminated in the environment. As this is the first study of its kind in Nepal, similar further studies are suggested with some retrospective studies in community acquired water borne MDR bacterial diseases.

\section{Conclusion}

The number of MDR bacteria was alarmingly high for the effluent samples from hospitals. Simultaneous resistance for most of the antibiotics including Penicillins, Cephalosporins, Cotrimoxazole, Gentamycin and Quinolones formed the MDR pattern. In case the resistance is transferred to bacterial pathogens causing infections in the communities, most of the currently available antimicrobials will not work against the infectious microorganisms. Therefore, this study indicated the need of establishment and regulation of healthcare liquid waste management practice in healthcare institutions to decrease the risk of disseminating pathogenic and multiple drug resistant microorganisms in the community for the safeguard of peoples' health.

\section{Acknowledgements}

This research was carried out with the financial support from World Health Organization (WHO). We wish to thank Mr. Han Heijnen, WHO Environmental Health Advisor of WHO country office, Nepal for providing grant to do this research successfully. We are very much indebted to the department of community medicine and family health for laboratory works and the respondents of Kathmandu based central hospitals of Nepal for their supports in information collection. 


\section{References}

1. Yadav CS, Devkota S, Aryal S. Healthcare Waste Management Training Manual for Medical Professionalas. Kathmandu: WHO/ NHRC (World Health Organization/ Nepal Health Research Council). 2002.

2. WHO [homepage on the internet]. Geneva: World Health Organization [cited on July 2008]. Healthcare Waste Management Manual. Available from: http://www.who.int/topics/ medical_waste/en/.

3. NWSC. Annual Report. Kathmandu: Nepal Water Supply Corporation, 2001.

4. Ku"mmerer K. Resistance in the environment. Journal of Antimicrobial Chemotherapy. 2004; 54: 311-20.

5. Kolpin DW, Furlong ET, Meyer MT, Turman EM, Zaugg SD, Barber LB et al. Pharmaceuticals, Hormones, and Other Organic Wastewater Contaminants in U.S. Streams, 1999-2000: A National Reconnaissance. Environmental Science and Technology. 2002; 36(6): 1202-11.

6. Smith K E, Besser J M, Hedberg C W, Leano F T, Bender J B, Wicklund J H et al. Quinoloneresistant Campylobacter jejuni infections in Minnesota, 1992-1998. The New England Journal of Medicine. 1999; 340: 1525-32.

7. House of Lords Select Committee on Science and Technology: $7^{\text {th }}$ Report of House of Lords (UK). London: The Stationery Office; 1998.
8. Hiraishi A. Respiratory quinone profiles as tools for identifying different bacterial populations in activated sludge. Journal of General and Applied Microbiology. 1998; 34: 39-56.

9. Chitnis V, Chitnis D, Patil S, Kant R. Hospital effluent: A source of multiple Drug-resistant bacteria. Current Science. 2000; 79 (7).

10. Islam M J, Uddin M S, Hakim M A, Das K $\mathrm{K}$ and Hasan M N. Role of Untreated Liquid Hospital Waste to the Development of Antibiotic Resistant Bacteria. Journal of Innovation and Development Strategy. 2008; 2(2): 17-21.

11. Oteo J, Navarro C, Cercendo E, Iribarren AD, Wilhelmi I and Orden B et al. Spread of $E$ coli strains with high level of Cefotaxime and Ceftazidime resistance between community, long term care facilities and hospital institutions. Journal of Clinical Microbiology. 2006; 44(7): 2359-66.

12. Huang H, Flynn N M, King J H, Marchand C, Morita M and Cohen S H. Comparisons of community associated MRSA and hospital associated MRSA infections in Sacramento, California. Journal of Clinical Microbiology. 2006; 44(7):2423-27.

13. Walton JR. The Veterinary Record. 1988; 122: 249-51. 